\title{
J
}

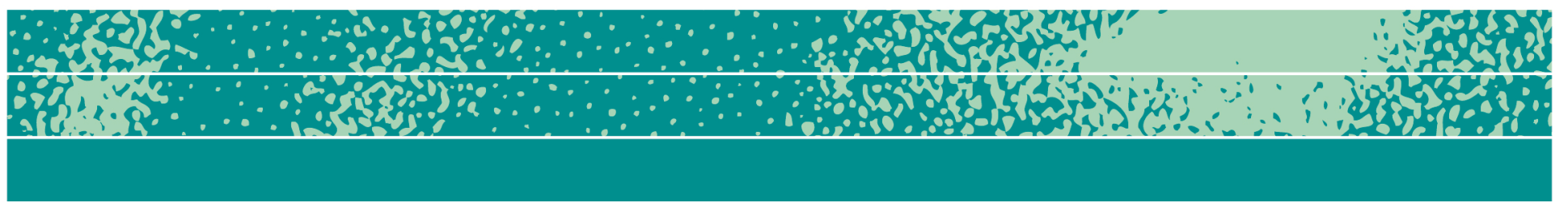

\section{His Master's Voice? Conceptualizing the Relationship Between Business and the World Economic Forum}

\author{
Christina Garsten \& Adrienne Sörbom
}

\begin{abstract}
Commonly, the relationship between corporations and non-for profit organizations, such as foundations, think tanks and private research institutes, is analyzed in terms suggesting that when acting as funders corporations set the frames for the non-for profit organization who, in turn, not only mimics but also serves as to broadcast the views of its funder. Drawing on the case of the Swizz based foundation/think tank World Economic Forum and its corporate funders we scrutinize this relationship. We show that as an organization interested in global policy making it is of vital importance for the Forum to construct its own agency, not merely giving voice to its funder's views, and that it will do so drawing on the resources that the funders provide. Moreover, we submit that as organizations all partaking actors will endeavor to construct their own agency, oftentimes by drawing on the resources of others. In so doing, actors may have both overlapping and divergent interests. Evoking the Lévi-Strauss concept of the bricoleur, we analyze how the various and multifaceted priorities of corporations will not only be filtered by the Form, but it will also make use of the resources at hand for organizing forth own policy messages. The result is a complex and dynamic web of actors and voices.
\end{abstract}

Page 1 of 22

JBA 8(1): 41-62 Spring 2019

(C) The Author(s) 2019 ISSN 2245-4217

www.cbs.dk/jba 


\section{Key words}

corporations, funding, think tanks, agency, World Economic Forum

\section{Introduction}

Tuesday, November 13, 2012. We are sitting in the magnificent lobby of the Mina A'Salam luxury hotel in Dubai with Dieter Weiss, executive at a leading global management firm. In the grand lobby, men and women, flawlessly dressed in official dress codes from across the world, stand small talking, exchanging news and gossip, talking on their phones, or waiting for a colleague, friend or partner. Mr. Weiss, who has not yet had his breakfast, invites us to join him, ordering cappuccino, orange juice and a sandwich. We decline, apart from the coffee. In half an hour, the Summit on the Global Agenda, organized by the World Economic Forum (WEF), will resume on its second day of meetings, to share ideas and options to address the grand challenges of the 21st century. The Mina A' Salam hotel, cast as 'a replication of images of ancient Arabia,' accommodates the majority of invited WEF strategic partners, business and government representatives who have flown in from all parts of the world for taking part in the summit.

Mr. Weiss, a modest looking man in his mid-fifties, is a leading member of the Global Agenda Council on the Arctic. The group is entirely new, and is according to Mr. Weiss created upon initiative of the WEF. This is the first Global Agenda Council (GAC) meeting that he participates in, and so far, Mr. Weiss is content with the work of the group. He describes it as meaningful and valuable. The group has decided to compose a shorter text about the Arctic. There are so many ideas about the Arctic, he says, ideas, which are not true. For example, Mr. Weiss explains, many believe the Arctic to be uninhabited, which as he explains is 'completely wrong'. In addition, Mr. Weiss underscores, business activities in the area have been on-going for a long time. The group wants to correct this faulty image of the Arctic and describe what the current challenges are. Mr. Weiss is honest about the fact that he himself knew little about the Arctic before he joined the group. But, as he states, he is well experienced in leadership, organizational developments, and business opportunities, which are core concerns for developing business in the area. The other members of the group are business representatives, government officials, and researchers, who as Mr. Weiss contribute their knowledge to the discussions. A big issue for the Arctic to develop, as the group sees it, is the fact that there are parts of the Artic that no one owns, in the legal sense, and therefore it cannot be claimed for business. This issue has to be solved. For the group the Arctic region is perceived as a new Klondike and future area of business. 'There is an unlimited amount of money to be made here,' Mr. Weiss says. The chief reason for him and his company to join the WEF and this particular GAC is the fact that most 
of the company's customers and competitors are also part of the group. In this sense, the WEF works as a magnet, a force that pulls on other business 'materials'. 'It's all about networking and branding,' Mr. Weiss claims.

The above episode illustrates the traction power and pulling force of the WEF among global business leaders and suggests some of their motives for engaging in what is essentially an extra-market activity with a non-profit foundation which intent is to secure a place for itself on the international political arena. Commonly, the relationship between corporations and non-profit organizations, such as foundations, think tanks and private research institutes, is analyzed in terms suggesting that when acting as funders corporations set the frames for the non-for profit organization who, in turn, not only 'mimics' but also serves to broadcast the views of its funder (cf. Lindberg \& Czarniawska 2006). Drawing on the case of the WEF and its corporate funders we take a closer look at this relationship, suggesting that as an organization interested in global policy making, it is of vital importance for the WEF to construct its own agency, not merely giving voice to its funder's views, and that it does so by drawing on the resources that the funders provide. The WEF, like LeviStrauss' bricoleur, makes do with the resources at hand in shifting ways, oftentimes by providing space and context for its 'masters' - the funders but not neccesarily by itself acting as a loudspeaker for these masters. In this manner, WEF events - with the Davos meeting as the prime showcase - serve as 'field-configuring events' (Moeran \& Strandgaard Pedersen 2011) where social and economic capital is created, for the WEF and its funding corporations to be put to use in their efforts to influence the global governance of markets.

\section{Molding the Environment}

Many global business leaders today do much more than engage narrowly in their own corporation and its search for profit. At a general level, we are seeing a proliferation of usages of non-market corporate strategies, such as testimony, lobbying, interlocking of positions and other means to influence policymakers at all levels of government and international institutions as an adjunct to the firm's market strategies (Barley 2010; Lawton et al 2012). As has for example been shown by Barley (2010) in the case of the US, corporations have systematically built an institutional field during the 1970s and 1980s to exert greater influence on the US Federal government. The resulting network, he argues (2010 p. 777), 'channels and amplifies corporate political influence, while simultaneously shielding corporations from appearing to directly influence Congress and the administration.' Conversely, there is an enhanced interest on the part of policymakers to influence firm behavior through multi-stakeholder involvement, public - private agreements and 
networks forms of governance (Scherer \& Palazzo 2011). Supporting and partaking in the events set up by organizations in the format of for instance private research institutes, think tanks, and foundations such as the WEF, is one avenue for these activities.

We take inspiration from Barley's study and wish to contribute to the understanding of how corporations fund and support think tanks in their interest of molding their environments. While earlier research on the theme of corporate funding of think tanks has been successful in analyzing who funds what, and who partakes in which events, thus establishing a link between corporations and this type of organization, (e.g. Carroll \& Carson 2003; Carroll \& Sapinski 2010; van der Pijl 2007), the more exact relationship between the two is less analyzed. Analysis commonly rests upon, or silently departs from, the assumption that relationships between a corporate funder and the receiving organization are of a one-way character (e.g. Arin 2014; Barley 2010; Carroll \& Carson 2009; Sklair 2002), indicating that the latter will not have much say or an agency of its own. Corporations are, according to this line of argument, thought of as depositing their ideas and intentions, through the medium of money, into the think tank that is believed to diffuse these ideas. Our intention is to complexify the understanding of the relationship between corporations as funders and think tanks as receivers, by suggesting that both parties will strive to establish and maintain their own agency, and in so doing may have both overlapping and divergent interests. The relationship is thus characterized as being contingent, dynamic and interdependent in a phenomenological fashion (Aspers 2010),

Epistemologically, it entails a plea for analyzing the relationship as a process of interpretation, translation and adaptation in between actors. Since ideas are constructs, they cannot 'travel' as fixed entities but will be translated and adopted by the actors relating to and thus re-constructing them (Czarniawska \& Sévon 1996). As Bruno Latour reminds us, 'the spread in time and space of anything - claims, orders, artifacts, goods - is in the hands of people; each of these people may act in many different ways, letting the token drop, or modifying it, or deflecting it, or betraying it, or adding to it, or appropriating it' (Latour 1986 p. 267). This constructive aspect is further underscored when ideas travel between organizations, as an organization generally will strive to establish its own agency and needs to accommodate the ideas in relation to its own intents (Czarniawska \& Joerges 1996).

In the interest of conceptualizing the relationship between corporations and think tanks, this article brings to the fore the role of business in the WEF. In so doing we will analyze how corporations draw on WEF to advance both financial and political interest, as well as how WEF relates and expands its own agency and voice based on its corporate funder's interest in partaking in WEF activities. Empirically the paper builds on ethnographic fieldwork at and around meetings organized by 
the WEF in places such as Cape Town, Davos, Dubai and Istanbul, as well as interviews with staff at the headquarters in Cologny, Switzerland, from the period of January 2011 to June 2015 . $^{1}$ Theoretically we draw on the notion of 'bricolage' as first introduced by Lévi-Strauss (1966), but extend its usage to shed light on certain practices of global policy actors.

The first part of the article introduces the WEF (also called the Forum), its Annual Meetings in Davos and the organization as such. The notion of the policy bricoleur is then introduced, as a way to capture to the agile role of the WEF in relation to funders and other stakeholders. We then go on to conceptualize the ways in which corporations may work to influence the identification of problems, the shaping of agendas, and the proposition of policy through their engagement with the WEF. Finally, we discuss our findings and suggest that the engagement of corporations in the WEF allows for a variety of pathways through which corporate leaders may shape and influence the perception of political problems, frame debates, and contribute to the crafting of propositions and scenarios. Importantly, however, the WEF cannot merely be seen as an extension of its funding masters. The relationship is built on mutuality, indicating that corporate participation is also a means by which the WEF itself, as a policy bricoleur, may amplify its own voice. The various and multifaceted priorities of corporations participating in this global think tank will not only be filtered by it, but it will also make use of the resources at hand for organizing their own policy messages. The result is a complex and dynamic web of actors and voices.

\section{World Economic Forum - the Organization}

The World Economic Forum is formed as a private foundation, with headquarters in Cologny, just outside of Geneva, Switzerland. It was founded in 1971 by Professor Klaus Schwab as the European Management Forum, under the patronage of European Commission and European industrial associations. The first forum was attended by 444 participants from a wide range of West European firms, concentrating on

\footnotetext{
${ }^{1}$ The ethnographic material consists of transcriptions of observation and informal conversation undertaken in and around WEF meetings in Cape Town, Davos (from three consecutive years), Dubai and Istanbul, as well as two meetings arranged by WEF-event participants in Stockholm, and about 35 recorded and transcribed interviews with Forum staff in WEF headquarters, Geneva. But for Chairman Klaus Schwab the identities of all informants are confidential. Original names of individuals and corporations, as well as titles, nationality and line of industry have been altered. Gender, age and relation to the Forum have most commonly not been altered, in order to provide for the general picture of participants and staff. None of the persons accepting to participate in recorded interviews demanded their identities to be concealed. Still, revealing their identity is of little importance in regards to a fair and robust analysis of the WEF. All conversations with informants that were not recorded, were made aware of us coming from Stockholm university, and that we were talking to them based on our academic interest of the WEF and our capacity as social scientists.
} 
how European firms could catch up with US management methods (Pigman 2007 p. 9). During the first years of existence Schwab (who in 2019 is still Executive Chairman of the WEF) launched what he termed 'the stakeholder model,' arguing that even though for example unions, NGOs, nation-state governments and business associations differ from each other in views, they may be stakeholders around the same particular issues, and therefore at times need to meet. This idea has since 1974, when the first politicians were invited, been the signature idea for the Forum as an organization

In the 1980s the mission of the organization was expanded in two interrelated ways. First, the Forum broadened its activities to include informal gatherings in diplomatic and political matters. For example, in 1982, cabinet-level officials and leaders of multi-lateral organizations such as the World Bank (WB), the International Monetary Fund (IMF) and the General Agreement on Tariffs and Trade (GATT), were invited to an informal gathering outside of the Annual Meeting. Second, in 1987 the Forum changed its name, signaling a move from targeting Europe and management, to a broader focus on the World and global issues (Pigman 2007 pp.14-15). The expansion also meant a considerable broadening of Forum activities in terms of time and space. Although the earlier version of the Forum had included meetings and summits apart from the Davos event, it gradually expanded these kinds of activities. The Annual Meeting in January was complemented with a number of activities all around the year, and all over the globe. The expansion did not occur without difficulties. Both managers and funders of the Forum internally raised criticism for not focusing enough on the needs of the corporations (Interview September 2004). ${ }^{2}$

At present, approximately 600 employees staff the Cologny headquarters, with the figure in constant increase since the widening of the Forum outlook. It is situated at the shore of the Geneva lake - right across the UN - in a modern-looking, grey building that had to be rebuilt in order to not only supply office space for the expansion of staff, but also for hosting the many informal meetings that are set up in the building. Its geographical location opposite the white UN building metaphorically stands testimony to the WEF being something of an alternative organizational model to the established international institutions - a notion oftentimes commented upon by staff.

Drawing on the works of Tom Medvetz (2012b), we conceptualize the Forum as a think tank, and as such a boundary-spanning organization, situating itself in-between the fields of business, politics, academia and media. It does so partly by hiring staff from all the fields, but more importantly it offers a space for meetings and deliberations for invited

\footnotetext{
${ }^{2}$ Interview conducted by Adrienne Sörbom together with Associate Professor Hans Abrahamsson, Department of Global Studies, Gothenburg University.
} 
actors from these fields. This space, structured and organized by the Forum centrally, may be employed in a blend of interests, such as individual, political and business benefits. Based on the various forms of participation on behalf of these actors the Forum will, in turn, construct and diffuse own policy initiatives.

\section{Policy Bricolage and Political Affairs}

Historically, especially in the US, foundations, think tanks and policy institutes have played a significant role in producing, advancing, and utilizing policy-relevant knowledge (Kingdon 1984; Barley 2010; Medvetz $2012 b$ ). Notable examples are foundations such as Ford, Nuffield, Aga Khan, Gates Foundation, the Soros Foundations Network, and think tanks such as Brookings, Carnegie, and RAND. Knowledge produced in such organizations often aim precisely at targeting political audiences and at influencing policy and political decision-making. Increasingly, think tanks have come to function as funnels for corporate influence, channeling and amplifying corporate interests (Campbell \& Pedersen 2014; Medvetz 2012a, 2012b; Rich 2004, Smith 1991; Stone 1996, 2013; Stone and Denham 2013). With corporate political activity having been the subject of state regulation for quite some time, corporate political activity, or corporate attempts to shape government policy in ways favorable to the firm (see for example Hillman, Keim \& Schuler 2004), has had to seek new routes. Think tanks stand out as one of the channels through which corporate political activity may be routed (Barley 2010; Stone 1996). Business leaders with an interest in investing profits in a larger social project, of 'doing good', may achieve leverage for their ideas through think tanks. The upsurge of the World Economic Forum in the area of global political affairs manifests these trends, funded by corporate capital in the leveraging of what is meant to function as policy-relevant knowledge and inviting [corporations?] to discussions regarding the form and shape of global politics as well as the role in global politics for nongovernmental actors.

While there is ample evidence to the argument that corporations 'populate the information environment with a variety of seemingly independent and unconnected organizations' (Miller \& Harkins 2010 p. 573), the more exact relationship between corporations as funders of think tanks is not fully analyzed. There are notable examples regarding how for instance the health, tobacco and alcohol industries finance and intervene in political activities, where the relationship is scrutinized in detail (e.g. McGarrity \& Wagner 2008; Hawkins \& McCambridge 2014). In general though, the most common analysis of this relation is based on the logics of 'guilt-by-association.' That is to say, if corporations fund a political organization of some sort, this is alleged to indicate that they are also influencing the outcomes of the organization's activities (e.g. Abelson 
2009; Arin 2014; Carroll \& Carson 2009; Sklair 2002). This association is indeed reasonable and few social scientists would question that funding entails influencing. It needs, though, to be further explored. Empirical scrutinizing and theoretical clarification of what goes on inside these types of organizations in regards to the question of relations towards funders may radically develop the understanding of what influencing on behalf of corporations mean and how that shapes think tank activities (van der Pijl 2007). Our in-depth case of the WEF, based on first-hand ethnographic observation and varying degrees of participation, interviews and document analysis, brings empirical evidence into the conceptualization of how corporations interact with think tanks, in this particular case with an interest in shaping global policy making.

Organizations set up or used by corporations for political interests often describe themselves in ambiguous terms, being simultaneously foundations, non-governmental organizations, research institutes and think tanks. The WEF is a pertinent case here, concurrently describing itself as a foundation, a non-profit organization, and a think tank. As mentioned above, its membership consists of 1,000 large-scale transnational corporations, who provide the funding base for the organization. With different types of encounters, some oriented to enhancing business opportunities and some oriented towards the political aspects of business, such organizations may alternate between positions and roles in the market and in political circles (cf. Medvetz 2012a). Its organizers speak with corporate leaders, tapping their knowledge and experience, but also with high-level politicians, providing a 'safe place' (as the WEF lingo has it) for informal discussions, as well as with civil society leaders on urgent issues impacting on, for instance, the global economy. In this sense, the WEF and similar organizations may be seen as constructing global policy bricolage and a form of polycentric governance, mixing disorderly processes and institutional reassemblages (Mittelman 2013). Just like the economic entrepreneur recombines and makes creative use of existing resources, capitalizing on the capacity to mobilize practical knowledge in a way that challenges general theoretical approaches (Baker, Miner \& Eesley 2003), WEF mobilizes by combining resources, social as well as economic, provided by its corporate funders as well as other types of event participants. This bricoleur character provides the WEF with an agility to operate across market and policy spheres, cobbling together various actors in the political landscape. Moreover, its status as a foundation, recognized by the Swiss state as an 'international institution' and non-profit organization opens up for deliberations beyond the scope of international organizations (such as the United Nations), where its non-state character makes it a useful arena for informal gatherings of the political and corporate elites.

The bricolage character of WEF activities is to some degree explicable by the precarious political mandate enjoyed by organizations 
drawing heavily on corporate funding. With expansionist ideas, political zeal, and often globalist visions, they aim to influence the sense-making and actions of policy-makers and politicians on a global scale. The challenge stems from the fact that their legal status denies them such influence, in the direct sense. Unlike international organizations such as the United Nations or the OECD, they do not represent the nations in which they are situated, nor do they represent any membership contingent other than the corporations. Thus, they work by mobilization and attraction (e.g. Nye 2004), relying on the power of persuasive arguments (Fischer and Forester 1993) and the social capital (Bourdieu 1986) they can muster through members and guests. In Lakoff's words, they prepare the seedbed of our brains with their high-level general principles (2008 p. 239).

Fliegstein (1990 p. 4) contends that 'the worlds' of top managers have always been highly structured and their actions shaped by social and political contexts.' Corporate managers tend to see the world from a certain perspective, but their specific points of view change along with social and political tides and how they need to act to keep their corporation afloat, as it were. Corporate leaders who are keen to look after their interests in new emerging markets, to voice their views on impeding regulations, or to prepare new markets for investments by working against corruption, therefore have good reasons to involve themselves in the work of boundary-spanning organizations such as think tanks and research institutes. The growth of the institutional field that has emerged, Barley (2010) argues, has in the US given rise to an almost impenetrable network of relations between corporations on the one hand, and policy-makers and politicians, on the other. Political actions committees, think tanks, and PR firms may thus shield corporate political influence in effective ways (2010 p. 796).

From the other side, as policy-makers and politicians grapple with the challenges of globalization, governance gaps, and evermore complex policy issues, they seek out the advice of knowledgeable professionals in the field, thus drawing corporate managers and others into their deliberations (Campbell \& Pedersen 2014). At the global level, where political institutional arrangements are weak, corporations, think tanks and foundations are pivotal in contributing to the construction of a global domain of politics and markets (c.f. Braithwaite \& Drahos 2000; Ruggie 2004). This global domain is multilayered, involving local, regional, state, and transnational operations alongside and intertwined with each other. It is fragmented, decentralized and diffuse compared to nation-state based domains of governance (Scholte 2005). It operates through consultations, coordination, and consensus-seeking. In these processes, representatives of corporations and corporate-sponsored organizations may consult, negotiate and make decisions with representatives of state departments, international organizations and multilaterals (well 
described in Braithwaite \& Drahos 2000). At the WEF, the ways in which corporate funders of the organization may get leverage for their ideas are manifold. We identify four general routes through which this may happen: funding, marketing and selling, in- and outsourcing and 'deep lobbying'. These routes can, however, not be described as merely 'corporate'. In the interest of enhancing its own agency and amplifying its own voice, the Forum also draws upon these routes in an interplay with funders. In the below, we will describe these strategic but contingent routes in more detail.

\section{Funding}

Financially, the WEF is built on its 1,000 funders, internally termed 'members', which are accepted by the WEF since they are seen as 'companies that run the world economy forward.' Their contributions steam the WEF engine and constitute the most fundamental way of relating to the Forum. As is well captured by Barley in his analysis of how corporations were 'building an institutional field' in the US, funding is the core corporate activity in political affairs (Barley 2010).

The typical funding company has about $\$ 5$ billion in revenues, and is rated as one of the most prominent in the industry or the country in which the company operates. Funding within the WEF is, however, stratified, ranging in between 60,000 to 600,000 Euros, allowing more influence to those who are willing (and accepted by the Forum) to pay more for being part of the extended network. A company may for example be invited to enter the 'Industrial Partnership,' which is linked to certain privileges, and is open only to roughly 300 selected companies. These privileges then entail more exclusive access opportunities to the different networks and activities of the Forum, such as the 'Governors meeting' and selected regional meetings. 'The Strategic Partnership' is reserved for merely 100 selected companies, and consequently costs more. This category is, as the WEF describes it, at the center of the 'Forum's knowledge generation activities' (www.weforum.org, accessed April 26 2016). For all of the funders, irrespective of level of contribution, it happens that they are invited to send at least one participant to the Annual Meeting in Davos, but the number of invitations varies in accordance with the ranking of the funder. Moreover, only funders paying the largest dues may enter into the restricted sections of the meeting. They are also offered a private car and a driver, something which ordinary members and most guests are not allowed to use.

Corporate funding is thus a pivotal way of supporting the WEF, and a way for a corporation to buy a place at WEF events. Funding does not, however, entail decision making in the internal affairs of the WEF. As is common in many think tanks, WEF funders do not know in detail exactly what their contributions will be used for. They pay for their 
'membership', and the Forum then continues to build and develop the organization along the lines of its statutes, but funders do not have any direct control of what the money is used for. They cannot, for example, appoint other funders and themes at events, nor can they talk in the name of the Forum. The group named 'Strategic and Event Partners', paying most and speaking with the strongest voice, provides general directions to the Forum, but does not constitute its highest decision body. The highest rank is given to the Board of Trustees, which is set up by a mixture of 'exceptional individuals who act as guardians of its [WEF's] mission and values, and oversee the Forum's work in promoting true global citizenship' (www.weforum.org accessed November 2 2016). Thus, funders may complain, but internally the Board of Trustees is not held accountable to them.

Rather than a possibility to directly influence what the Forum does by democratic procedures via the so called 'membership', in the Forum, the relationship between the funders and the WEF can be characterized as a business deal, or as high-ranking manager Cassius Luck described the relation, 'I think they are in a sense our subscribers. They are subscribing to an agenda that is not set by them' (interview June 2015). By funding WEF, corporations are buying themselves an arena where they can do business. For a corporation with global ambitions the WEF-funding is a form of recognition that opens the door to being appreciated at a global level as among the prime actors in their area of business. To be in Davos is to be seen, and to see others. Harry Woodpecker, one of our informants, a senior manager at a global consultancy firm, describes his company's interest in WEF as tied to a chance of being given the keys to the Davos event. Being there means demonstrating to others that you are on the same playing field, and that you are someone of weight, chosen by the Forum as one of the drivers of the economy in their business field.

Indeed, corporate funding does provide the Forum with the resources needed to set up the Davos event. But support from CEOs of corporations is not enough for the WEF, as an actor interested in policy making. If they were to be content with only that, they would merely send a signal saying that the Forum is a form of chamber of commerce and, as declared to us by a high-level manager at the Forum, that is not what the Forum intends to be. Leaders from the world's largest corporations must gather together with political tycoons of many sorts to ensure the image of the Forum as an important actor in global governance. Therefore, there is a constant in-house haggling with regard to whom to invite, with quotas to fill in the various categories the Forum sees as 'stakeholders' in global policy making. In the end, every event must be a harmonious blend of 'business' and 'non-business' (as the WEF staffers refer to the categories). The funders on their behalf complain that they pay substantial sums of money but do not get as much as they want out of it. As Peter Bond, a high-level manager in a global consultancy corporation that has been a 
WEF-funder for many years, told us somewhat critically and disappointingly, his company could only bring four participants to Davos. In spite of all the money and time they spent on the Forum he would still not be let into the inner circles, something that he found strange.

\section{Marketing and Selling}

Funding thus grants corporations the right to participate at WEF events, but it does not grant them the right to govern the organization, nor access to its inner circles. Aspiring to be an actor on the global policy scene, decoupling funders from organizational governance is a matter of agency for the Forum. It effectively seeks to be in control of its own voice. Still, the Forum needs its funders, not only for financial reasons but also, and more importantly, as a social resource. One pivotal aspect of Forum events is therefore that they can function as a marketplace. Without this function many funding corporations would have difficulties legitimizing the costs of attending WEF meetings and participating in other types of WEF activities. In practice, the meeting in Davos, as well as regional and other thematic meetings, are used by funders to arrange meetings among themselves and to talk about possible deals, potentially also closing them.

We observed this marketplace function up close at a WEF Regional Meeting in Istanbul. At each meeting there is a 'networking area' where people mingle, date, and talk, oftentimes about business. During the three days that we spent at this meeting we were based in the networking area - where we were observing and chatting with participants (wearing white badges) and 'hangarounds' (such as ourselves without badges). As Hans Klerk explained to us - working for a networking company that had been denied access as participants by the Forum, but welcomed to approach people in the networking area - he would do business from there. His interest was to deliver as many leads as possible back to his company, that is, names of people they could contact as possible business partners. In the same vein, a young fashion designer from Turkey, sitting beside us, took the opportunity to show her collection to Annisa Darmadi, a 'Young Global Leader' (one of the many Forum categories of people attending) from Indonesia, who by Wikipedia is described as 'an influential media personality.' For the designer, the chat was a time for marketing, whilst for Darmadi it was a time for coaching (and maybe getting some new inputs that she could use in her work). At an adjacent lunch table sat Jan de Vries, a badge-wearing participant working for a socially oriented hedge fund, in the midst of a long row of scheduled meetings. Small-scale meetings were thus taking place all around us, in the interstices of formal, orchestrated meetings.

The Forum not only stages the networking area, it also helps its funders out in many other ways. In Istanbul we also met with Peter Andrade, from a global insurance company, who sat down beside us in a 
sofa, and declared that he has accomplished what he had ultimately come for. So far, he had skipped the WEF-sessions, instead occupying himself with a number of pre-arranged meetings. These took place not in the networking area but in a small room that the Forum had set up for him. Hakan Yilmaz, his colleague, still had some mingling to do, though. To him the most important aspect of the meeting was to meet people and to be seen. - It is expensive, he said, but worth every penny since he would come home with new opportunities for business at the same time as he had learnt something about the political context of the meeting.

The Forum is also willing to help out more directly in business deals. As one informant at the headquarters in Cologny explained to us, a government official from a country who is, for example, interested in rebuilding the telecom network, can contact the Forum to ask for help. The Forum can then act as a broker, facilitating discussions between governmental officials and CEOs from relevant companies by arranging meetings at, for instance, the Davos event.

Another of our informants, Mr. Gunnlaugson, is a director of an influential foundation, whom we met at the Annual Meeting in Davos. In the cozy warmth of a pizza restaurant just inside the secured gates of the meeting ground, Mr. Gunnlaugson brushed the snow from off his long grey winter coat and took a seat at the table. To him, and to many others, he explained, the chief reason for coming to Davos is the fact that everyone else of importance be will be here. He asserted that 'If you are not here, you do not exist. Everyone who counts in our business is here. We are here to meet and to discuss.' The event is a magnet for influential leaders from all over the world, and a convenient meeting spot. With everyone's agenda filled up, attending the Davos meeting is synergetic, in combining time, place, and issue. Over lunch and a beer, he also explained that going to Davos is a long-term investment, since nurturing and maintaining network ties takes a while, and one might not see the results immediately. 'But if you want to be in the game, you need to be here.'

A large share of the frenzy in Davos, Istanbul, and other places where the Forum touches ground is thus about markets in action - selling and buying, but also embedding (trans)actions in social relations. By and large the meetings function as trade fairs, as described by Morean (2011a). Drawing on the "visibility factor" (Moeran 2011b) the event acts as a framing mechanism by which participants can come together for the exchange of goods and services. Corresponding to fashion fairs (Skov 2006), WEF events function as interfaces for global market actors. For WEF-funders, the market-related activities oftentimes legitimize their attendance at meetings which public agendas focus political issues, while at the same time granting WEF the corporate attendance it requires for constructing the specific and spectacular blend of both political and business tycoons that is an essential part of its allure. In so doing, the Forum achieves the leeway it requires for being the global policy maker it 
aspires to be.

\section{Insourcing/Outsourcing}

The headquarters in Cologny and the international staff working there make up the organizational hub of WEF, not merely by way of governing the organization, but also more generally in the format of framing and producing the activities and the products that come out of it. It is in Cologny that future funders are chosen, invitees selected, publications written, indexes constructed, and so forth. Funding corporations do not have any of their staff placed at headquarters, although they can come to visit for shorter or longer periods. Overall, this entails that funders are decoupled also from the everyday organizing of WEF. Interpreting this dayto-day set-up in terms of the communication constitutive of organization (Coreen et al. 2011), we would claim that a substantial part of all WEF activities are shaped, formatted, and phrased by the organization itself, thus mastering its own voice and agency.

Still, WEF offers many opportunities for corporations to use their voices too, under the WEF-logo. The credibility and authority of WEF relies to a large extent on the 'brain power' of the individuals it can attract and keep in its orbit. It positions itself as a platform for dialogue and knowledge-seeking around complex and urgent global issues drawing upon knowledge from what is presented as relevant stakeholders. Onto this platform, people from 'all walks of life,' described as intelligent, excellent, and experienced, are invited for the WEF to tap into their ideas and expertise. As a standard, individuals from funding corporations or other business make up half of all participants in these activities. To some extent, and taken together, these 'experts' of the WEF form part of what Diane Stone (2008: 24) refers to as 'transnational policy professionals.' They are treated as knowledge actors that have 'intrinsic governance capacities' (cf. Stone 2012) to define problems, and to shape the climate of the debate.

In the WEF context these policy professionals are organized into so called 'communities.' For instance, the funding 1,000 funding companies is seen as one community, which as the Forum describes it, forms one of its key pillars. It 'facilitate[s] the Forum's mission of improving the state of the world' and to 'address urgent issues, explore emerging trends and help' (http://www.weforum.org, accessed 26 April 2016). Other examples of 'communities' are the 'Global Leadership Fellows,' the 'Young Global Leaders,' and the 'Global Shapers,' to mention but a few.

Perhaps the most interesting example of how corporate leaders have an opportunity to take active part in what comes out of the WEF is the community based upon the 'Network of Global Agenda Councils' (later renamed and reconstituted as 'Global Future Councils'). Involved in these are over 1,500 'experts' contributing to 'a network of invitation-only 
groups that study the most pressing issues facing the world' (www.weforum.org, accessed 26 April 2016). This community congregates at the yearly event in Dubai, where we met with Mr. Weiss. During three days these WEF proclaimed experts, informally termed 'the world's brain trust,' deliberate in small groups on WEF-given themes. The net result may be booklets, indexes, suggestions for organizational changes, or merely suggestions for themes and topics at the next Davos event. Since the groups are working under Chatham House Rule (always applied at WEF activities), ensuring confidentiality of the source, it is not possible for the audiences of these products to link perspectives or suggestions to a particular author. Importantly, though, the specific outcomes will always by monitored by the Forum, or even be written by it, providing scope for it to align contents with its own particular interest.

Funders may also be insourced and drawn upon in WEF activities in the format of the many reports that emanate from the Forum organization itself. Oftentimes, Forum staff in Cologny writes these, but it is not rare that they are produced jointly with leaders of funding corporations. What typically will happen is that the Forum will gather a group to work on a particular theme as part of raising a new initiative. The group will have a WEF-employed coordinator but it will be made up by a number of people from the 'stakeholder groups' that WEF conjures, of which funding corporations are one. As Pablo Pimentel, WEF-manager in Cologny, explained to us, the initiative is more or less dependent on somebody within the group stepping up and taking the lead. The project may then be run by, for example, one of the funders, who in practice assigns someone from within its own corporation to do the job. Finally, the report is negotiated within the group, as well as with the Forum, so that it may speak for both the members of the group and the Forum.

In these communities, funders, as well as other participants, are freely drawn into the world-wide network that the WEF is constructing. They are insourced as holders or deliverers of potentially valuable ideas and knowledge, which later on are elaborated upon, translated into the WEF vocabulary, or discarded, by the organizational core. By the same token, in a reciprocal move, when WEF taps into the expertise of these partakers they are outsourcing part of their knowledge-seeking to other individuals and organizations. By these double transfers, the WEF invites a mix of business and non-business actors into their activities. By interlocking activities, through the testing of ideas and crafting of knowledge, the writing of reports and policy statements, the WEF is thus partly shaped by, but also shaping, its funders and invitees.

\section{Deep Lobbying}

Our corporate informants have aired the significance of the WEF as an arena for 'value creation' in the broad sense of the term. By this, they 
refer to the fact that engaging in the activities of the WEF, meeting other corporate and political leaders of similar weight, may not be instantly rewarding from a market point of view, but may in the long run shape discussions in a way that may have an impact on regulations and the structure of markets. This is 'deep lobbying' (Clemons 2003), in the sense that what happens is that the intellectual climate and discourse around an issue may be changed by a continuous process of social interaction and networking.

At the WEF Summit on the Global Agenda Council meeting in Dubai in November 2012, Mr. Bond - a high-level director at one of the Strategic Partners of WEF - described the importance of WEF from point of view of value creation. He had been involved in working groups, or 'communities,' at the WEF for a number of years, and had attended Davos meetings several times. Over dinner, he told us that it was actually at the informal meetings in the interstices of the formal program that the more interesting discussions happened. Once, he told us, his working group had gone out for dinner, and this was when the important breakthrough came about. 'It is really the informal gatherings that are value-creating,' he put it. Being among the selected few, knowing that oneself and all the other participants have been carefully scrutinized and judged to pass, one can rest assured that the ties nurtured within the realm of WEF may work to influence people's perception of an issue, to raise awareness, and to place the issue on a future agenda. It is deep lobbying among 'the best of brains,' as WEF staff would have it.

In Davos we attended a closed lunch discussion, not announced in the official program. The lunch was organized as a possibility for a number of actors to meet and discuss questions regarding the Arctic. Participating at the lunch were among others one prime minister, a few members from the Arctic Council, scientists and representatives from a number of corporations interested in the area. A few of the participants were offered the possibility of introducing their views on the topic, while the others were eating. Discussions around the small round tables were then encouraged and fed back to the larger group. In this small setting, the attending prime minister told the corporations about possible alternative conventions. The participating CEOs on the other hand talked about the challenge and the importance of establishing guidelines for corporations, perhaps headed by WEF? Somebody else claimed that in the long run it would cost more to not use the oil in the Arctic, than using it. The scientist rose and tried to inspire the participants to think of the environmental consequences.

Access to meetings such as this lunch is part of the deal between the corporations and the WEF. An integral part of its offer to funders is the construction of a global stage, where corporations may appear in front of a selected global audience. Simultaneously, the WEF offers a back stage, closed for the eyes of the global public. The WEF provides at once a front 
stage, where business leaders can be seen and recognized by a significant part of the business community, and a back stage, where business leaders may meet in private, in the 'safe places' provided by the WEF. In Goffmanian terms (Goffman 1959), the WEF provides the 'setting,' or context, in which front- and backstage business performance is then shaped. In this setting, positions and interests may be aired and articulated.

The lunch discussed above is an exemplary case of a designed backstage setting where 'deep lobbying' can take place - where participants can sit down at the lunch table, socialize, and talk relatively freely around a hot topic, away from media attention. As opposed to more obvious forms of lobbying, the sharing of views at this lunch was not an attempt from the corporation to influence the direction of a specific decision. Rather, it is about molding the environment in a direction that is favorable to the participating actors (cf. Barley 2010). Deep lobbying in the context of the WEF is about mobilizing the network around a particular issue and position. This is in its most effective mode (cf. Nye 2004). On this arena, WEF plays the role of the broker, bringing together and mediating between actors and interests. For the WEF, these types of events are particularly important to their bricolage activities, since they serve to extend the agency of the organization. For corporate leaders, they provide as well a place for moving business ahead. WEF events may thus turn out to be equally propitious and rewarding for all parties involved.

\section{Concluding Notes: Amplification and Bricolage}

In this paper, we set out to explore the relationship between corporations and think tanks by drawing on the case of WEF. Our aim has been to find and term conduits by which corporate funders may relate to a think tank, such as the WEF, and analyze how a think tank in turn may expands its own agency based on corporate funding. Drawing on Latour's understanding of translation as central to the understanding of power (Latour 1986), our point of departure was to interpret this relationship as dynamic and indeterminate, plausibly involving mimetic behavior (Lindberg \& Czarniawska 2006) on behalf of the receiver of financial support with regards to the political priorities, perspectives, and ideas of the funding corporations. As we have argued, though, any form of mimesis of ideas will take the form of continuous translations in between the actors involved. The notion of 'policy bricolage' was introduced as a way to capture the ambiguous, creative and agile role of WEF in relation to its funders. Like the bricoleur in the Lévi-Straussian sense (1966), WEF draws upon a repertoire of material and immaterial resources from which it assembles and adapt its funders' ideas, perspectives and priorities, thereby carving out its own position and constructing an agency of its 
own. In this sense, the WEF events - with the Davos meeting as the prime showcase - functions as field-configuring events (Moeran \& Strandgaard Pedersen 2011) where social and economic capital is created, often beyond the awareness of the WEF.

We found a number of conduits through which business may deploy the WEF and its platforms for both market and extra-market activities, at the same time as WEF uses these for constructing its own agency. First, membership dues grant corporate access to the many communities and activities of the WEF, at the same time as these dues steams, in both financial and social terms, the WEF. Second, business finds the WEF to be a strategic place from which they may market and sell products and services. This is a position that WEF secures for them in the interest of granting social and economic resources to its own policy related activities. Third, as WEF outsources parts of its knowledge-seeking to partakers in its communities, thus drawing on these other's resources, this also entails that funders may contribute its ideas when being insourced to WEF. Fourth, the WEF is an arena for 'deep lobbying', whereby corporate leaders connect to political leaders and partake in framing policy discourses and impacting the intellectual climate around an issue, at the same time as WEF achieves the role it seeks in global policy making.

Corporations thus find a strategically positioned amplifier for their non-market interests in the WEF. The WEF provides a global stage, as it were, where business leaders may present themselves as global players where the visibility aspect of participation is most clearly put to work. Moreover, by being there ideas, perspectives and solutions may travel from corporate funders into the think tank, as well as to other types of participants (politicians, journalists and so forth), who in turn may pick up, mimic, and transform the perspectives of corporate funders. In so doing the WEF may amplify the voice of corporations in the broader political landscape.

By the same token, though, the WEF should not be conceived as the extended voice of corporations in a direct sense, as if it was merely broadcasting its master's voice. As the metaphor of the bricoleur implies, WEF also makes use of the corporations to organize and expand its own agency, which does not necessarily coincide with the interests of its funders. There is no organizational mechanism for funders to demand accountability of Forum activities. The use of voice within the WEF is therefore precluded; what is left is exit. Moreover, in practice it is essentially the Forum itself that sets the frame of its activities by selecting funders, setting themes, constructing initiatives, picking out moderators et cetera. In so doing the WEF may at times mimic some of its funders' interests. What is important, however, is to see the relationship between the two as constructed, founded on choice, and not determined by financial predicaments. The global policy bricolage of the WEF is not a 
form of unequivocal corporate global governance, but an intricate system of interweaving market and political interests, and one that both amplifies and blurs the choir of voices. The WEF constructs its own network through which social, cultural and economic capital may be leveraged for its own specific interests.

More broadly, how and to what extent a think tank will be able to make its own choices irrespective of its funders will depend on how relations to stakeholders are set up. For instance, the 'astroturf' organizations that Barley describes (Barley 2010, p. 790), set up by corporations as temporary organizations for a specific cause, may take the shape of a think tank. In such an instance, the relationship is less open for choice, rendering it less plausible for the think tank to set its own framework. What this article has shown, though, is the need for analyzing the nuanced relationship between funders and think tanks. Since ambiguity, indeterminacy, and heterogeneity across agents (of all sorts) is to be expected in organizing, this needs to be anticipated even in the case when corporations fund political activities. Analysis resting upon, or silently departing from, the assumption that relationships between a corporate funder and the receiving organization are of a one-way character may not aptly capture the role of neither funders nor the actions of the think tank. The ties are more complex and intricate than that.

\section{References}

Abelson, D. E. 2009. Do Think Tanks Matter? Assessing the Impact of Public Policy Institutes. 2nd Edition. Montreal: McGill-Queen's University Press.

Aspers, P. 2010. 'The Second Road to Phenomenological Sociology.' Society 47 (3) $214-219$.

https://doi.org/10.1007/s12115-010-9306-6

Arin, K.Y. 2014. Think Tanks: The Brain Trust of US Foreign Policy.

Wiesbaden: Springer Fachsmedien. https://doi.org/10.1007/978-3-658-02935-7

Baker, T., A.S. Miner, and D.T. Eesley 2003. 'Improvising firms: Bricolage, account giving, and improvisational competency in the founding process.' Research Policy 32 (2): 255-276.

https://doi.org/10.1016/S0048-7333(02)00099-9

Barley, S. 2010. 'Building an institutional field to corral a government: A case to set an agenda for organization studies.' Organization Studies 31 (6): 777805.

https://doi.org/10.1177/0170840610372572 
Bourdieu, P. 1986. 'The Forms of Capital', in J. G. Richardson (ed.) Handbook of Theory and Research for the. Sociology of Education. New York: Greenwood Press. Pp. 241-258.

Campbell, J. K. and O. K. Pedersen 2014. The National Origins of Policy Ideas: Knowledge Regimes in the United States, France, Germany, and Denmark. Princeton: Princeton University Press. https://doi.org/10.23943/princeton/9780691150314.001.0001

Clemons, S. C. 2003. 'The corruption of think tanks.' JPRI Critique, X(2).

Braithwaite, J. and P. Drahos 2000. Global Business Regulation. Cambridge: Cambridge University Press.

Fliegstein, N. 1990. The Transformation of Corporate Control. Harvard: Harvard University Press.

Goffman, I. 1959. The Presentation of Self in Everyday Life. New York: Random House.

Granovetter, M. S. 1973. 'The strength of weak ties.' American Journal of Sociology 78 (6): 1360-80.

https://doi.org/10.1086/225469

Hawkins, B. and J. McCambridge 2014. 'Industry actors, Think tanks and Policy in the United Kingdom.' American Journal of Public Health 104 (8). https://doi.org/10.2105/AJPH.2013.301858

Hillman, A. J., G. D. Keim and D. Schuler 2004. 'Corporate political activity: A Review and Research Agenda.' Journal of Management 30 (6): 837-857. https://doi.org/10.1016/i.jm.2004.06.003

Lakoff, G. 2008. The Political Mind: Why You Can't Understand 21st Century Politics With an 18th-Century Brain. New York: Penguin Books.

Latour, B. 1986. 'The powers of association.' In J. Law (ed) Power, Action and Belief, A New Sociology of Knowledge?. London: Routledge and Kegan Paul.

Lawton, T., S. McGuire and T. Rajwani 2012. 'Corporate political activity: A literature review and research agenda.' International Journal of Management Reviews 15 (1): 86-105.

https://doi.org/10.1111/j.1468-2370.2012.00337.x

Lévi-Strauss, C. 1966. Savage mind. Chicago: Chicago University Press.

Kingdon J.W. 1984/2011. Agendas, Alternatives and Public Policies. New York: Longman.

McGarrity, T. and W. Wagner 2008. Bending Science: How Special Inter 7 ests Corrupt Public Health Research. Cambridge, MA: Harvard University Press.

Medvetz, T. 2012a. 'Murky power: 'Think tanks' as boundary organizations.' 
In D. Courpasson, D. Golsorkhi, and J. J. Sallaz (eds) Rethinking Forms of Power in Organizations, Institutions, and Markets. Bradford, UK: Emerald Group Publishing, pp. 113 - 33.

https://doi.org/10.1108/S0733-558X(2012)0000034007

Medvetz, T. 2012b. Think Tanks in America: Merchants of Policy and Power. Chicago: University of Chicago Press. https://doi.org/10.7208/chicago/9780226517308.001.0001

Miller, D. and Harkins, C. 2010. 'Corporate strategy, corporate capture: Food and alcohol industry lobbying and social policy.' Critical Social Policy 30 (4): 564-589.

https://doi.org/10.1177/0261018310376805

Mittelman, J.H. 2013. 'Global Bricolage: emerging market powers and polycentric governance.' Third World Quarterly 34 (1): 23-37.

https://doi.org/10.1080/01436597.2013.755355

Moeran, B. 2011a. 'Trade Fairs, Markets and Fields: Framing Imagined as Real Communities.' Historical Social Research, 36 (3): 79-98.

Moeran, B. 2011b. The Ursula Fainence Dinnerware Series by Royal Copenhagen. Copenhagen: Copenhagen Business School.

Moeran, B. and Strandgaard Pedersen, J. 2011. Negotiating Values in the Creative Industries. Cambridge: University Press. https://doi.org/10.1017/CB09780511790393

Nye, J. S. 2004. Soft Power: The Means to Succeed in World Politics. New York: Public Affairs.

Pigman, G. A. 2007. The World Economic Forum: A Multi-Stakeholder Approach to Global Governance. London: Routledge. https://doi.org/10.4324/9780203962756

Rich, A. 2004. Think Tanks, Public Policy, and the Politics of Expertise. Cambridge: Cambridge University Press. https://doi.org/10.1017/CB09780511509889

Ruggie, J. G. 2004. 'Reconstituting the global public domain: Issues, actors and practices.' European Journal of International Relations 10 (4): 499-531. https://doi.org/10.1177/1354066104047847

Scherer, A.G. and G. Palazzo 2011. 'The new political role of business in a globalised world: A review of a new perspective on CSR and its implications for the firm, governance and democracy.' Journal of Management Studies 48 (4): 899-931.

https://doi.org/10.1111/i.1467-6486.2010.00950.x

Scholte, J. A. 2005. Globalization: A Critical Introduction. Basingstoke: Palgrave Macmillan. 
https://doi.org/10.1007/978-0-230-21207-7

Sklair, L. 2002. 'The Transnational Capitalist Class and Global Politics: Deconstructing the Corporate: State Connection.' International Political Science Review 23 (22): 159-174. https://doi.org/10.1177/0192512102023002003

Skove, L. 2006. 'The Role of Trade Fairs in the Global Fashion Business', Current Sociology 54 (5): 764-783.

https://doi.org/10.1177/0011392106066815

Stone, D. 2013. Knowledge Networks and Transnational Governance: The Public-Private Policy Nexus in the Global Agora. Basingstoke: Palgrave Macmillan. https://doi.org/10.1057/9781137022912

Stone, D. 2012. 'Governance via Knowledge: Actors, Institutions and Networks.' In D. Levi-Faur (ed) OUP Handbook of Governance. Oxford: Oxford University Press.

Stone, D. 2008. 'Global public policy, transnational policy communities and their networks', Policy Studies Journal 36 (1): 19-38. https://doi.org/10.1111/j.1541-0072.2007.00251.x

Stone, D. 1996. Capturing the Political Imagination: Think Tanks and the Policy Process. London: Frank Cass.

Stone, D. and A. Denham (eds) 2004. Think Tank Traditions: Policy Research and the Politics of Ideas. Manchester: Manchester University Press.

Christina Garsten, Ph.D. is Principal of Swedish Collegium for Advanced Study and Professor of Social Anthropology at Stockholm University. She co-authored Discreet Power: How the World Economic Forum Shapes Market Agendas (Stanford University Press, 2018), with Adrienne Sörbom.

Adrienne Sörbom, Ph.D. is professor of Sociology at Stockholm and Södertörn University. She is the co-autior to Discreet Power: How the World Economic Forum Shapes Market Agendas (Stanford University Press, 2018), together with Christina Garsten. 